\title{
A new species of Myotragus Bate, 1909 (Artiodactyla, Caprinae) from the Early Pliocene of Mallorca (Balearic Islands, western Mediterranean)
}

\author{
PERE BOVER* $\S_{\S}$, JOSEP QUINTANA $\ddagger \&$ JOSEP ANTONI ALCOVER*§ \\ *IMEDEA (CSIC-UIB), Institut Mediterrani d’Estudis Avançats, Departament de Biodiverstat i Conservació, \\ Cr Miquel Marquès 21, 07190 Esporles, Illes Balears, Spain \\ $\ddagger$ Cr Gustau Mas 79-1er, 07760 Ciutadella de Menorca (Illes Balears, Spain) \\ $\S$ Research Associate, Division of Vertebrate Zoology/Mammalogy, American Museum of Natural History, \\ Central Park West at 79th Street, New York 10024 NY, USA
}

(Received 10 August 2009; accepted 1 March 2010; first published online 23 April 2010)

\begin{abstract}
Myotragus palomboi n.sp. (Artiodactyla, Caprinae) is described from the Early Pliocene of Mallorca (Balearic Islands, western Mediterranean). This species is the earliest representative of the Myotragus lineage known to date in the Balearic Islands. A metatarsal, and several teeth and postcranial remains were found in a karstic deposit located on the east coast of the island, near Caló den Rafelino (Manacor), together with remains of Hypolagus, two rodent species, an insectivore and several reptiles. The metatarsal and phalanges of the new bovid are short and robust and display a combination of characters only observed in Myotragus. The presence of a larger p2, a metatarsal robustness index lower than in $M$. pepgonellae (the earliest known species to date), together with the morphology of the incisors, all suggest that M. palomboi should be considered as the ancestor of M. pepgonellae. Short metapodials and the reduction of $\mathrm{p} 2$ displayed by M. palomboi could be linked to a first stage of evolution in insular conditions. The arrival of this bovid to the island of Mallorca probably took place during the Mediterranean Messinian Salinity Crisis (Late Miocene, 5.6$5.32 \mathrm{Ma}$ ago). Although the relationship of the new taxon to other fossil caprines cannot be definitively established, it could be phylogenetically close to the Late Miocene European species Aragoral mudejar and Norbertia hellenica.
\end{abstract}

Keywords: Myotragus, new species, Early Pliocene, Mallorca, taxonomy.

\section{Introduction}

The fossil record of caprines (Caprinae, sensu Gentry, 1992) in the Mediterranean islands is restricted to the Balearic Islands and Sardinia. On Mallorca, five chronospecies belonging to the Myotragus phylogenetic lineage have been described, spreading from the Early-Middle Pliocene to the Holocene (Alcover, Moyà-Solà \& Pons-Moyà, 1981; Bover \& Alcover, 2005): M. pepgonellae (Early/Middle Pliocene), $M$. antiquus (latest Middle Pliocene), M. kopperi (latest Pliocene/Early Pleistocene), M. batei (Early/Middle Pleistocene) and M. balearicus (Middle Pleistocene to Holocene). Two species are known to occur on Menorca, namely, Myotragus balearicus and a second one from an Early Pleistocene deposit described as M. binigausensis by Moyà-Solà \& Pons-Moyà (1980), although it was later synonymized to M. batei by Bover $\&$ Alcover (2000), a view recently questioned (MoyàSolà et al. 2007). M. balearicus, the terminal species of the lineage, survived on Mallorca and Menorca presumably until the first human arrival, 4300-4200 years ago (Bover \& Alcover, 2003; Alcover, 2008). Evolutionary patterns within Myotragus include body size reduction (insular dwarfism), changes in skull and

$\dagger$ Author for correspondence: perebover@imedea.uib-csic.es postcranial morphology, and reduction in number of incisors and premolars. M. balearicus displays a single ever-growing incisor in each jaw, and a single premolar in the lower dentition (p4) and two in the upper dentition (P3 and P4) (Bate, 1909; Andrews, 1915). Similar changes in dentition have occurred in other island bovids. Thus, both species of the Alcelaphini genus Maremmia, M. haupti and M. lorenzi from the Late Miocene of the Tusco-Sardinian palaeoprovince (Hürzeler \& Engesser, 1976; Hürzeler, 1983; Azzaroli et al. 1986), also display one lower premolar and two upper premolars, although the Maremmian bovid has three ever-growing incisors in each jaw. Turritragus casteanensis (unassigned subfamily and tribe status, neither Neotragini nor Alcelaphini: M. R. Palombo, pers. comm.) from Casteani (Grossetto) and Fiume Santo (Sardinia) displays just one lower premolar and two upper premolars (Abbazzi et al. 2008).

On the island of Eivissa ('Ibiza'), a faunal assemblage was discovered in the beginning of the 1980s at Ses Fontanelles, a Late Miocene/Early Pliocene deposit (Moyà-Solà et al. 1984). Two bovids were initially identified: a very hypsodont and small-sized Antilopini, and a Bovidae (Caprinae) with short metapodials (Moyà-Solà, Agustí \& Pons-Moyà, 1984; Agustí \& Moyà-Solà, 1990; Moyà-Solà et al. 1999). 
Table 1. Measurements (in mm) of dental and postcranial remains of Myotragus palomboi $\mathrm{n}$. sp.

\begin{tabular}{|c|c|c|c|c|c|c|c|c|}
\hline Bone & & & & Meast & ments & & & \\
\hline $\begin{array}{l}\text { Upper dentition } \\
\text { P2 } 90142 \\
\text { P3 } 90275\end{array}$ & $\begin{array}{l}\mathbf{L} \\
6.5 \\
8.3\end{array}$ & $\begin{array}{l}\text { W } \\
6.7 \\
10.8\end{array}$ & $\begin{array}{l}\text { Hli } \\
6.6 \\
5.3\end{array}$ & $\begin{array}{l}\text { Hla } \\
14.5 \\
10.8\end{array}$ & & & & \\
\hline $\begin{array}{l}\text { Lower dentition } \\
\text { p2 } 90143 \\
\text { p2 } 90144\end{array}$ & $\begin{array}{l}\mathbf{L} \\
6.2 \\
5.2\end{array}$ & $\begin{array}{l}\mathbf{W} \\
4.6 \\
4.9\end{array}$ & $\begin{array}{l}\mathbf{H m} \\
6.1 \\
8.6\end{array}$ & $\begin{array}{l}\text { Hd } \\
4.5 \\
4.6\end{array}$ & & & & \\
\hline $\begin{array}{l}\text { Magnum } \\
90272 \\
90273\end{array}$ & $\begin{array}{l}\text { TD } \\
18.2 \\
18.4\end{array}$ & $\begin{array}{l}\text { APD } \\
19.7 \\
19.4\end{array}$ & $\begin{array}{l}\text { APFL } \\
15.7 \\
17.6\end{array}$ & $\begin{array}{l}\mathbf{A C M} \\
11.7 \\
12.1\end{array}$ & $\begin{array}{l}\mathbf{A C m} \\
10.5 \\
10\end{array}$ & & & \\
\hline $\begin{array}{l}\text { Pisiform } \\
90138\end{array}$ & $\begin{array}{l}\text { TD } \\
5.6\end{array}$ & $\begin{array}{l}\text { APD } \\
14.4\end{array}$ & $\begin{array}{l}\text { DVD } \\
10.7\end{array}$ & & & & & \\
\hline $\begin{array}{l}\text { Astragalus } \\
90131\end{array}$ & $\begin{array}{l}\text { GLI } \\
30.6\end{array}$ & $\begin{array}{l}\text { Bd } \\
17.9\end{array}$ & $\begin{array}{l}\text { Dm } \\
16.1\end{array}$ & $\begin{array}{l}\text { DI } \\
17.6\end{array}$ & & & & \\
\hline $\begin{array}{l}\text { Metatarsal } \\
90140\end{array}$ & $\begin{array}{l}\text { GL } \\
86.8\end{array}$ & $\begin{array}{l}\text { TD } \\
19.8\end{array}$ & $\begin{array}{l}\text { APD } \\
14.7\end{array}$ & $\begin{array}{l}\text { TDp } \\
22.9\end{array}$ & $\begin{array}{l}\text { TDd } \\
22.4\end{array}$ & $\begin{array}{l}\text { APDp } \\
19.2\end{array}$ & $\begin{array}{l}\text { APDd } \\
14.8\end{array}$ & \\
\hline $\begin{array}{l}\text { Proximal phalanx } \\
90132 \\
90133 \\
90274\end{array}$ & $\begin{array}{l}\text { GL } \\
27.4 \\
25.7 \\
30.4\end{array}$ & $\begin{array}{l}\text { TD } \\
10.5 \\
10.6 \\
-\end{array}$ & $\begin{array}{l}\text { APD } \\
11 \\
10.2 \\
-\end{array}$ & $\begin{array}{l}\text { TDp } \\
12.2 \\
11.6 \\
-\end{array}$ & $\begin{array}{l}\text { TDd } \\
10.9 \\
10.1 \\
-\end{array}$ & $\begin{array}{l}\text { GLPe } \\
23.9 \\
22.6 \\
-\end{array}$ & $\begin{array}{l}\text { BFp } \\
11.3 \\
11.2 \\
-\end{array}$ & $\begin{array}{r}\text { BFd } \\
10.3 \\
9.4 \\
-\end{array}$ \\
\hline $\begin{array}{l}\text { Medial phalanx } \\
90134 \\
90135\end{array}$ & $\begin{array}{l}\text { GL } \\
18 \\
19.5\end{array}$ & $\begin{array}{c}\text { TD } \\
9.7 \\
10.9\end{array}$ & $\begin{array}{l}\text { APD } \\
12.5 \\
11.1\end{array}$ & $\begin{array}{r}\text { TDp } \\
9.6 \\
10.5\end{array}$ & $\begin{array}{l}\text { BFp } \\
10.8 \\
-\end{array}$ & $\begin{array}{l}\text { GLPe } \\
15.8 \\
19.4\end{array}$ & & \\
\hline $\begin{array}{l}\text { Distal phalanx } \\
90136 \\
90137\end{array}$ & $\begin{array}{l}\text { DLS } \\
31.6 \\
-\end{array}$ & $\begin{array}{c}\text { MBS } \\
10.6 \\
9.3\end{array}$ & & & & & & \\
\hline
\end{tabular}

Measurements of astragalus and phalanges following von den Driesch (1976). Collection numbers of specimens are also provided. Teeth: $\mathrm{L}$ - length; $\mathrm{W}$ - width; $\mathrm{Hm}$ - mesial height of the enamel; $\mathrm{Hd}-$ distal height of the enamel; Hli - lingual height of the enamel; Hla - labial height of the enamel. Postcranial: GL - greatest length; TD - transverse diameter at midshaft; APD - dorso-palmar/plantar diameter at midshaft; TDp - transverse diameter proximal; APDp - dorso-palmar/plantar diameter proximal; TDd - transverse diameter distal; APDd - dorso-palmar/ plantar diameter distal; GLPe greatest length of the peripheral (abaxial) half; BFp - proximal functional breadth; BFd - distal functional breadth; DLS - greatest diagonal length of the sole; MBS - middle breadth of the sole; GLl - lateral greatest length; Bd - distal breadth; Dm - greatest depth on medial side; Dl - greatest depth on lateral side; APFL - dorso-palmar/plantar functional diameter; $\mathrm{ACm}$ - medial height in dorsal view; $\mathrm{ACm}$ - lateral height in dorsal view; DVD - dorso-ventral diameter.

On Sardinia, a Plio-Pleistocene Caprinae was initially described as Antilope (Nemorhaedus) melonii by Dehaut (1911), although the genus Nesogoral was erected ulteriorly by Gliozzi \& Malatesta (1980) to accommodate this species from material obtained at Capo Figari (northeastern Sardinia). Remains of this caprine have been recovered from other deposits on the island, such as Capo Mannu (western central Sardinia: Van der Made, 1999), Monte Tuttavista (eastern Sardinia: Abbazzi et al. 2004) and from an unknown locality at Campidano (southwest Sardinia: Van der Made, 2005). Two species of Nesogoral have been described thus far: N. melonii (Dehaut, 1911) and N. cenisae Van der Made, 2005. In addition, four bovids were reported by Abbazzi et al. (2004) from Monte Tuttavista: Nesogoral sp.1 aff. N. melonii (morphotype A), Nesogoral sp.2 (morphotype B), ?Caprinae gen. et sp. nov. (morphotype C) and Caprinae gen. et sp. indet. The former morphotype $\mathrm{C}$ was described as Asoletragus gentryi (Palombo et al. 2006b), but its definitive ascription to the Caprinae could not be established. A close phylogenetic relationship between Nesogoral and Myotragus is widely accepted (e.g. Gliozzi \& Malatesta, 1980; Palombo et al. 2006a).

We describe here the remains of a caprine recovered at Caló den Rafelino (Manacor, east coast of Mallorca).
With this paper we wish to honour Miss Dorothea M. A. Bate, a pioneering fossil hunter from the beginning of the 20th century, who discovered and described the genus Myotragus after a short visit to Mallorca, exactly one hundred years ago (Shindler, 2005).

\section{Methods}

Postcranial bones and teeth of recent and fossil bovids used to establish comparisons with the new taxon are curated at three vertebrate collections: (1) 'Museu de la Naturalesa de les Illes Balears' (MNIB), deposited at the Institut Mediterrani d'Estudis Avançats (IMEDEA, Esporles, Mallorca, Spain) and Societat d'Història Natural de les Balears (SHNB, Palma, Mallorca, Spain); (2) the American Museum of Natural History (New York, USA); and (3) the National Museum of Natural History-Smithsonian Institution (Washington, D.C., USA). Measurements (to $0.02 \mathrm{~mm}$ ) were taken as defined in Table 1 caption using a digital caliper.

Measurements of additional recent and fossil caprines were derived from the literature: Guerin (1965) for Gallogoral meneghinii and additional recent caprines; Gliozzi \& Malatesta (1980) for Nesogoral melonii; Van der Made (1999) for Nesogoral aff. melonii and Van der Made (2005) for Nesogoral 


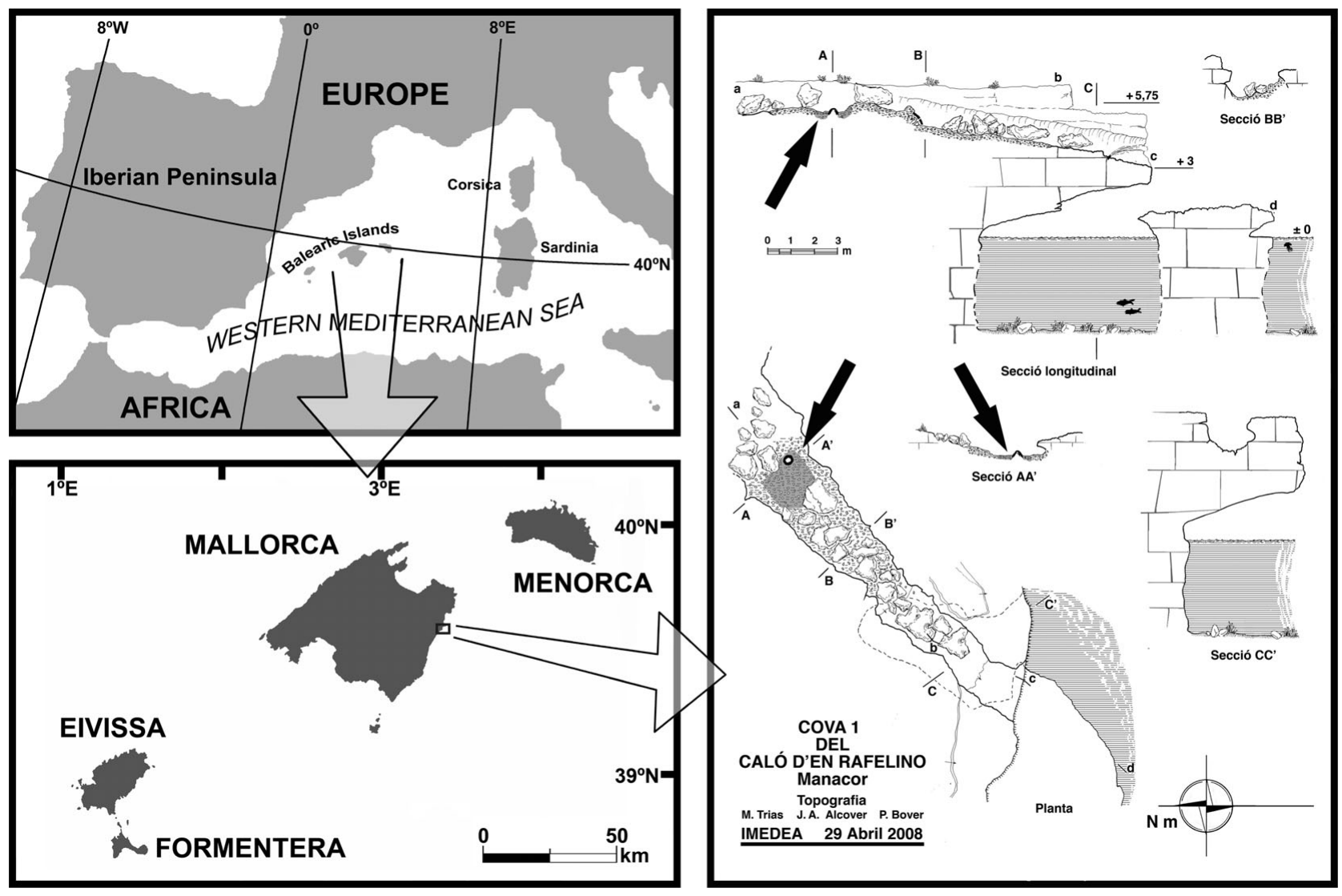

Figure 1. Location map (left) and topographic survey (right) of the palaeontological deposit from Caló den Rafelino. Arrows and grey coloured zone indicate the exact location of the fossiliferous breccia. Translation: 'secció' - cross-section, 'planta' - plan, 'secció longitudinal' - longitudinal section, 'topografia' - topographic survey and 'abril' - April.

cenisae; Palombo et al. (2006a) for Nesogoral sp.; Köhler, Moyà-Solà \& Morales (1995) for Norbertia hellenica; and Alcalá \& Morales (1997) for Aragoral mudejar.

The anatomical terminology used in the description follows Köhler (1993) for metatarsal and phalanges, Mead \& Taylor (2005) for cubonavicular (except 'internal' and 'medial' processes of these authors have been changed to 'medial' and 'central' processes, respectively, in this paper), and Schaller (1992) and Bover, Fornós \& Alcover (2005) for the rest of postcranial bones. Dental terminology is according to Gentry \& Hooker (1988) and Gentry (1992).

\section{Deposit}

The deposit is located on the eastern coast of Mallorca, close to Caló den Rafelino, in the municipality of Manacor (Fig. 1). It is very close to the seashore, and consists of hardened sediment belonging to one of the relatively common palaeo-collapses (e.g. Fornós, 1998; Robledo \& Pomar, 2000) present in the Upper Miocene limestones of the so-called Reef Complex (Pomar et al. 1990; Gómez-Pujol, Balaguer \& Fornós, 2007), Late Tortonian-Messinian in age (Bizon et al. 1973).

The fossiliferous deposit (Fig. 1) occupies a very small portion of the red silt sediment of the fossil cave (roughly $1 \mathrm{~m}^{2}$ ), and contains a faunal assemblage not recorded before in Mallorca. In addition to the caprine studied herein, remains of four mammals (a new species of Hypolagus, a large-sized new genus of cricetid, a glirid and a soricid), several reptiles (thus far, a large viperid, a colubrid, a tortoise, a lacertid and an anguid, and more may be identified), a bird and some fish teeth have been recovered (Bover et al. 2007; Quintana et al. in press).

\section{Description and comparisons}

Following the criteria of Gentry (1992) and Gentry, Rössner \& Heizmann (1999), the combination of characters displayed by the Caló den Rafelino bovid, such as short metapodials, weak flanges distally on metatarsals, dorso-plantar compression of metatarsal shaft, simple outline of central fossettes on upper molars, and reduced p2 (see description of material for further details) clearly favour its inclusion in the Caprinae. The lack of remarkable differences in size, the morphological consistency of the complete caprine bone sample obtained, together with the insular character of the fauna (as derived from absence of mammal predators, presence of endemic species, and characteristic changes in body size) suggest that all these remains belong to the same species.

The tentative Early Pliocene chronology of the deposit, the lack of Miocene bovids in the Balearic 


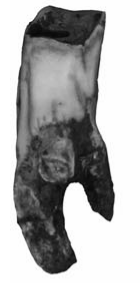

a1

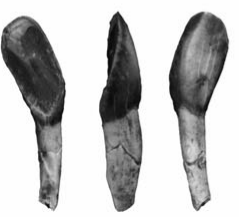

c1 c2 c3

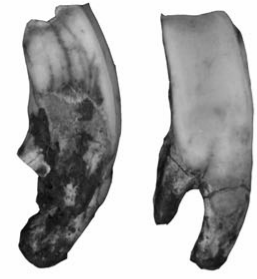

a3

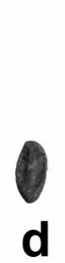

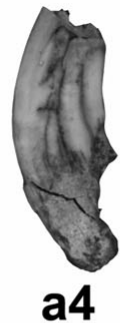
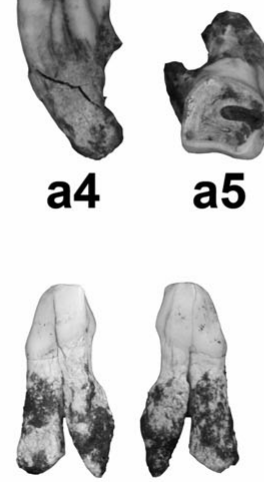

e1

e2
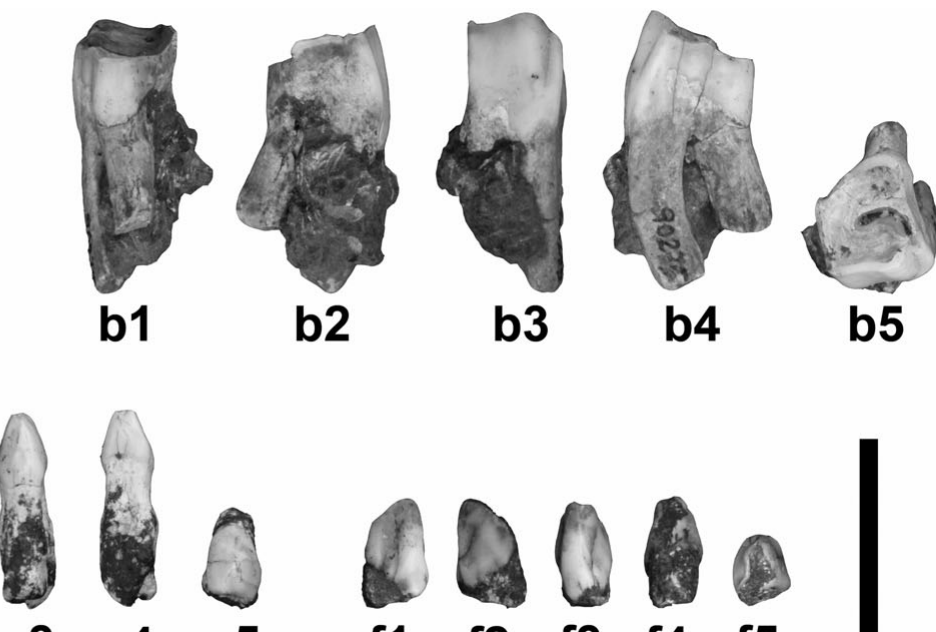

e3

e4
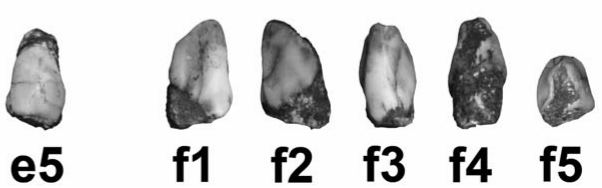

Figure 2. Dental material of Myotragus palomboi, n. sp. (a) left P2 IMEDEA 90142: 1 - lingual view; 2 - mesial view; 3 - labial view; 4 - distal view; 5 - occlusal view; (b) left P3 IMEDEA 90275: 1 - lingual view; 2 - mesial view; 3 - labial view; 4 - distal view; 5 occlusal view; (c) left i3 IMEDEA 90145: 1 - occlusal view; 2 - mesial view; 3 - labial view; (d) right dc IMEDEA 90146: occlusal view; (e) left p2 IMEDEA 90143: 1 - labial view; 2 - lingual view; 3 - mesial view; 4 - distal view; 5 - occlusal view; (f) right p2 IMEDEA 90144: 1 - labial view; 2 - lingual view; 3 - mesial view; 4 - distal view; 5 - occlusal view. Scale bar $2 \mathrm{~cm}$.

Islands, and the known Mallorcan faunal assemblage during the Pliocene and Pleistocene, all suggest that the recovered material should be compared with Late Miocene-Early Pliocene western European and Pliocene Balearic caprines in order to establish its phylogenetic relationships. Thus, comparisons between the caprine from Caló den Rafelino (CdR caprine) and Myotragus, Nesogoral and Gallogoral meneghinii (a mainland caprine from the Villafranchian of Europe (Guerin, 1965) that has been related to Myotragus (Alcover, 1976)) will be established. Although two species of Nesogoral have been described (N. melonii and $N$. cenisae), the main difference between them lies in the degree of metapodial robustness (those of $N$. melonii being more robust than $N$. cenisae) (Van der Made, 2005). Consequently, Nesogoral s.l. will be used in the comparisons except for the metapodials. We also compared the $\mathrm{CdR}$ caprine with a few remains from the caprine of Ses Fontanelles (Eivissa). Only the material of this caprine curated in Mallorca (Spain) has been available for comparative analysis.

Although several species of presumed Caprinae have been described from the Late Miocene of the Mediterranean-European region (e.g. Köhler, 1987; Alcalá, Morales \& Moyà-Solà, 1989-1990; Köhler, Moyà-Solà \& Morales, 1995; Gentry, Rössner \& Heizmann, 1999; Vislobokova, 2006), just one species has been recorded in the western European mainland: Aragoral mudejar (Late Vallesian) from Aragón (Spain). It displays a robust metacarpal and a hypsodont dentition with a reduced premolar row (Alcalá \& Morales, 1997). This species has been related to the more modern Norbertia hellenica from the Turolian/Ruscinian transition of Maramena (Greece) (Köhler, Moyà-Solà \& Morales, 1995). Although the latter species has not been recorded in western Europe, it will be considered when establishing comparisons because it has been phylogenetically related with Aragoral (Alcalá \& Morales, 1997).

In addition to the fossil caprines already listed, almost all recent caprines (Ammotragus, Budorcas, Capra, Capricornis, Hemitragus, Nemorhaedus, Oreamnos, Ovibos, Ovis, Pseudois and Rupicapra) have been included in the analysis, with special attention paid to Ovis, the closest relative to Myotragus according to molecular data (Lalueza-Fox et al. 2005; Ramírez et al. 2009).

\section{4.a. Upper dentition}

\section{4.a.1. Upper second premolar (P2)}

Material. IMEDEA 90142, left (Fig. 2a).

A very hypsodont tooth with subequal length and width in occlusal view. The tooth is slightly wider than long $(\mathrm{L}=6.5 \mathrm{~mm}, \mathrm{~W}=6.7 \mathrm{~mm}$; see Table 1$)$, and the labial wall is slightly concave, almost flat, with styles poorly developed or absent. No ribs on the labial wall can be observed. The parastyle is almost absent because it is extremely reduced, appearing as a small rib on the mesial side of the tooth. This weak parastyle is placed very close to the mesial extreme of the central cavity, which is mesio-distally elongated and placed on the mesial half of the tooth. This tooth is poorly developed mesially to the protocone, while distally it is large and expands lingually. The enamel is more extended on the mesial and labial walls than on the distal and lingual walls. The occlusal surface is worn and almost flat. The distal edge on the occlusal surface is sharp and divided into two lobes.

As remarked previously, the tooth of the $\mathrm{CdR}$ caprine is wider than long (ratio $\mathrm{L} / \mathrm{W}<1$ ), as in specimens of M. pepgonellae, Ovis vignei and Capra pyrenaica 
(P. Bover, unpub. data). The remaining fossil and extant caprines display a $\mathrm{P} 2$ which is longer than wide.

A partial maxilla of M. pepgonellae (MNIB 59199) bearing $\mathrm{P} 2-\mathrm{M} 3$ shows that the $\mathrm{P} 2$ displays the same morphology as in the CdR caprine. According to the description of the $\mathrm{P} 2$ of Norbertia hellenica, styles are absent and the tooth is longer than broad (Köhler, Moyà-Solà \& Morales, 1995). This morphology is similar to that displayed by the $\mathrm{CdR}$ caprine, $M$. pepgonellae and Gallogoral, although it might be related to the fact that these remains share the same level of wear. Like Norbertia, Aragoral mudejar has a longer than broad P2 (Alcalá \& Morales, 1997) and, as observed in the CdR caprine, its mesial side is reduced (area placed mesially to protocone poorly developed). No P2 of Nesogoral appears described or figured in the bibliography, and no P2 from Ses Fontanelles is available for study.

Although the morphology of this premolar is conditioned by wear, the shape in occlusal view of the Caló den Rafelino P2 is more similar to Ammotragus, Ovis and Capra than to other caprines. Differences among these taxa rely on the lesser development of the area placed mesially to the protocone in the $\mathrm{CdR}$ caprine and Ammotragus, and the presence of a labial projection of a feeble metastyle in Capra and Ovis.

\section{4.a.2. Upper third premolar (P3)}

Material. IMEDEA 90275, left (Fig. 2b).

Although the tooth is highly worn, it is clearly hypsodont. As in $\mathrm{P} 2$, the $\mathrm{P} 3$ is wider than long $(\mathrm{L}=$ $8.3 \mathrm{~mm}$; $\mathrm{W}=10.8 \mathrm{~mm}$; see Table 1 ). In occlusal view, it has a square-trapezoidal shape. The parastyle is very reduced and placed on the mesio-labial corner, and is expanded labially. The labial wall is also relatively flat and only the paracone prolongation to the root through the wall can be observed. The area placed mesially to the protocone is well developed and expanded lingually. The area placed distally to the protocone is poorly developed. The enamel is more expanded on the labial and medial walls. The central cavity is elongated and U-shaped. The medial extreme of this cavity is placed close to the parastyle, between the parastyle and the paracone. As in $\mathrm{P} 2$, the distal crest present on the occlusal surface is well marked and sharp. The occlusal surface is almost flat with a broad groove running in the lingual-labial direction.

A wider than long P3 (ratio $\mathrm{L} / \mathrm{W}<1$ ) is also displayed by $M$. pepgonellae (Moyà-Solà \& PonsMoyà, 1982), Gallogoral (Guerin, 1965) and some specimens of Capra and Ovis (P. Bover, unpub. data). Although this tooth is more hypsodont in $M$. pepgonellae, its morphology is very similar to the $\mathrm{CdR}$ caprine. Norbertia hellenica and Aragoral mudejar have a weak metastyle (like the CdR caprine), but they display a flat lingual surface, while in the CdR caprine this surface is strongly convex. Gallogoral and Nesogoral have a well-developed metastyle, but
Nesogoral has a weaker parastyle than Gallogoral, although it is more developed than in the $\mathrm{CdR}$ caprine.

Although the shape of the occlusal surface also seems to be influenced by wear, similarities in development of the protocone and parastyle between the CdR caprine and specimens of Ovis, Capra and Pseudois with similar tooth wear can be clearly noticed.

\section{4.b. Lower dentition}

\section{4.b.1. Third incisor (i3)}

Material. IMEDEA 90145, left (Fig. 2c).

This tooth has a typical chisel shape and displays a clear distinction between root and crown. It is not a very hypsodont tooth (crown length $9.5 \mathrm{~mm}$; crown maximum width $4.6 \mathrm{~mm}$; root length $8.2 \mathrm{~mm}$ ). The root is compressed mesio-distally and displays a shallow groove along the mesial side. The crown is labially curved, especially in ventral view. The wear surface has a subrectangular-oval shape. It is divided into two concavities by a medial rib and has a distinctive wear facet on the tip (labial extreme). The enamel has no longitudinal grooves and covers the entire crown region (except the wear surface).

In bovids, incisors and canines (incisiforms) usually fall from the mandible shortly after death. It is rare to get jaws retaining incisiforms in fossil specimens. When more than one species is present in the same deposit, it is difficult to assign isolated incisors and canines to one of them. Thus, for comparative purposes, only incisors and canines from recent caprines have been used, together with some teeth of Myotragus pepgonellae.

Although it depends on the wear conditions, the shape of this tooth in the CdR caprine is similar to the i3 of all caprine species studied except Myotragus. The general shape of the tooth is even more similar to Capricornis, Nemorhaedus and Rupicapra.

The $\mathrm{i} 3$ of $M$. pepgonellae displays a very different shape. It has a wear surface subtriangular in outline and is relatively hypsodont (Hypsodonty Index, HI: 2.12-2.22, calculated as crown total length/maximum crown width), but it is less hypsodont than the i3 of $M$. antiquus (HI: 3.1) (Moyà-Solà \& Pons-Moyà, 1982). The HI for the $\mathrm{i} 3$ of the CdR caprine is 2.06 , and its shape is completely different (see above).

\section{4.b.2. Deciduous canine or third incisor? (dc or di3?)}

Material. IMEDEA 90146, right (Fig. 2d).

Crown of a small incisiform, probably a deciduous canine. Crown length $5.5 \mathrm{~mm}$; crown maximum width $2.7 \mathrm{~mm}$. The outline of the crown is oval.

\section{4.b.3. Lower second premolar (p2)}

Material. IMEDEA 90143, left, 90144, right (Fig. 2e, f; Table 1). 
This is not a very hypsodont tooth (Table 1). Entoconid and entostylid are fused (entoconid-entostylid complex; fusion observed even in an unworn tooth, IMEDEA 90143). Paraconid and parastylid are also fused (paraconid-parastylid complex). The labial wall is almost completely flat, while there are two slightly marked ribs on the lingual wall. They correspond to the ventral expansion of the paraconid-parastylid complex and the metaconid. The paraconid-parastylid complex is small and reduced to a crest on the mesial margin of the tooth. The protoconid is just in front or placed slightly mesial to the metaconid. In the worn p2 (IMEDEA 90144) the metaconid and protoconid are the highest points of the tooth and are placed on the mesial margin of the occlusal surface. Thus, the occlusal surface is flat and obliquely inclined towards the distal part. In one of the specimens (IMEDEA 90143), two large roots can be observed.

In M. pepgonellae the presence of a second lower premolar remains controversial. In the description of the species by Moyà-Solà \& Pons-Moyà (1982), the presumed presence of an alveolus for a reduced $\mathrm{p} 2$ was reported, but Bover \& Alcover (2005) mentioned that it was not observable. Thanks to a recent exhaustive cleaning of the type of M. pepgonellae (MNIB 57321) and of a second mandible (MNIB 59196) of this species, both completely covered by an opaque layer of consolidant, the root of a small tooth was revealed mesially to the p3. It is unclear if it corresponds to a $\mathrm{p} 2$ or to a relict dp2. The size of this premolar should be extremely reduced in relation to a 'normal'sized premolar (alveolar length: $1.9 \mathrm{~mm}, 2.5 \mathrm{~mm}$; alveolar width: $2 \mathrm{~mm}, 2.9 \mathrm{~mm}$, respectively, in the two mandibles), and its shape should have looked like a small column (like the dp3 of M. balearicus; see Bover \& Alcover, 1999). The morphology of this tooth in the CdR caprine is more similar to the $\mathrm{p} 2$ of other fossil and recent caprines studied. Unfortunately, the unavailability for study of other premolars of the CdR caprine precludes the establishment of comparisons between the size of the $\mathrm{p} 2$ and the size of the $\mathrm{p} 3$ and $\mathrm{p} 4$, and thus of evolutionary changes or size reduction in this tooth. Nevertheless, the $\mathrm{p} 2$ is proportionally wider in the CdR caprine (W/L: 0.75 for IMEDEA 90143 and 0.95 for IMEDEA 90144; see Table 1) than in other caprines studied (W/L ranging between 0.55 and 0.67 except in very worn specimens, in which this ratio is higher). In other caprines studied (except Aragoral; p2 not figured in Alcalá \& Morales, 1997) the protoconid and metaconid are also the highest points of the tooth, but they are placed in the middle of the occlusal surface.

\section{4.c. Postcranial skeleton}

4.c.1. Magnum

Material. IMEDEA 90272, right, and 90273, right (Fig. 3a, b).

Like other postcranial remains, this bone is robust. It is slightly proximo-distally compressed, and the insertion areas of ligaments and tendons are poorly preserved, as occurs with the crests present on the articular facets. The separation between the semilunar and scaphoid articular facets is relatively low in dorsal view. The distal surface is completely flat and, while in specimen IMEDEA 90272 the articular facet for the metacarpal is expanded over all the surface, in IMEDEA 90273 there is a non-articular facet on the latero-palmar part of this surface.

One of the specimens (IMEDEA 90273) displays gnawing marks on the proximo-medial and proximodorsal margin of the bone, probably produced by a rodent (a cricetid and a glirid have been recorded in the deposit).

The only remarkable morphological feature of the magnum of the $\mathrm{CdR}$ caprine is the relatively low height difference between the semilunar and scaphoid articular facets. The ratio medial height/lateral height ( $\mathrm{ACM} / \mathrm{ACm}$; see Table 1) is low in the $\mathrm{CdR}$ caprine $($ mean $=1.16 ; \mathrm{n}=2 ;$ range $=1.11-1.21)$. Only $M$. kopperi $($ mean $=1.22 ; \mathrm{n}=2 ;$ range $=1.17-1.27)$ (no magnum of M. pepgonellae or M. antiquus is available), Budorcas $($ mean $=1.24 ; \mathrm{n}=3$; range $=1.15-1.28$ ) and Ovibos $($ mean $=1.18 ; \mathrm{n}=5$; range $=1.12-1.21$ ) show similar values. This ratio is markedly higher in the other species studied (e.g. Oreamnos; mean $=1.5 ; \mathrm{n}=$ 5 ; range $=1.41-1.59)$ and Nesogoral $(1.35 ; \mathrm{n}=1$, obtained from figured specimen in Van der Made, 2005).

\section{4.c.2. Pisiform}

Material. IMEDEA 90138, left (Fig. 3c).

The pisiform of the CdR caprine is robust and of globular shape. The articular facet for the unciforn and the ulna are separated by a ridge. For comparison only pisiforms of M. balearicus, Gallogoral, Oreamnos, Capra, Ovis, Rupicapra, Capricornis, Budorcas and Ovibos have been used. Although some features of the pisiform are very variable (Bover, Fornós \& Alcover, 2005), the general globular shape of this bone in the CdR caprine is very similar to M. balearicus, Oreamnos and Ovibos.

\section{4.c.3. Astragalus}

Material. IMEDEA 90131, left (Fig. 3d).

The astragalus is incomplete and partially eroded, but some of its features can be described. It is short and broad. The plantar articular facet for the calcaneus is concave but not very rounded and is extended distally. The groove placed between the two proximal trochleae is broad and deep, and in dorsal view it is closed Ushaped. In this same view, and although it is slightly eroded, the lateral proximal trochlea is placed above the level of the medial one, which is expanded plantarly.

Astragali from recent caprines Budorcas, Oreamnos, Capricornis, Ovibos, Ovis and Capra and fossil Myotragus, Nesogoral and Gallogoral have been compared with the astragalus of the CdR caprine. The 

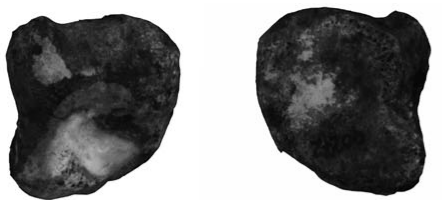

a1

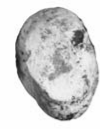

c1

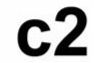

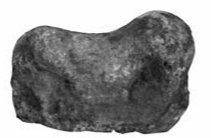

a3

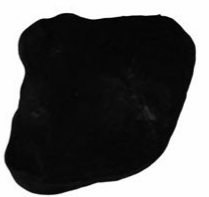

b1

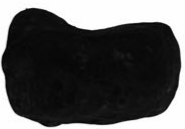

b2

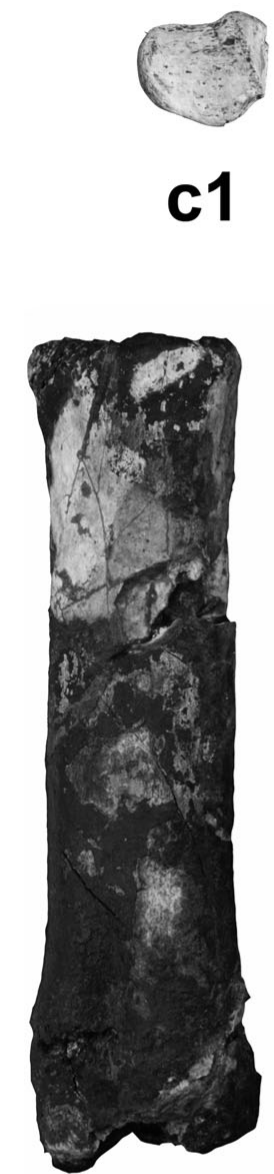

f1

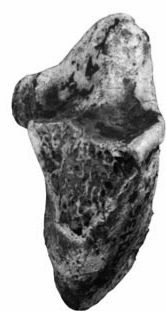

11

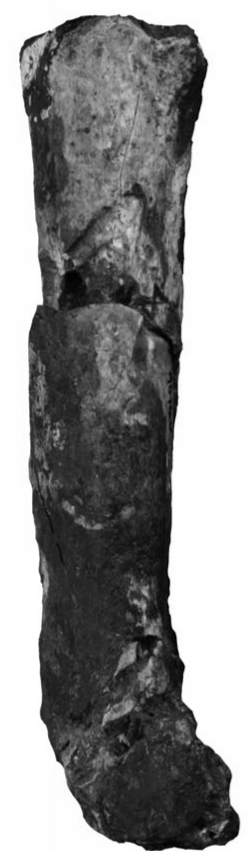

f2

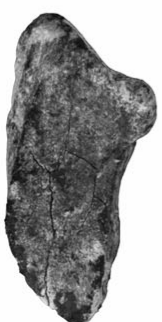

12

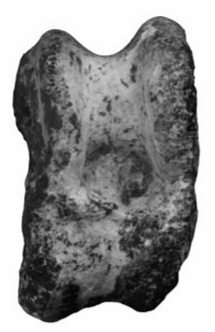

d1

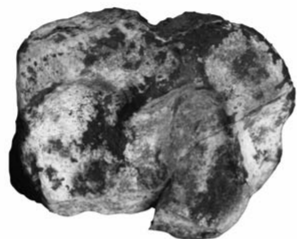

e1

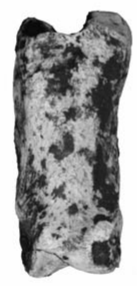

g1

g2

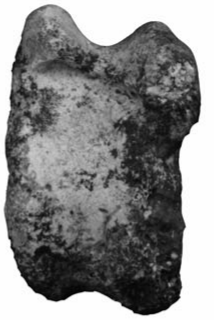

d2

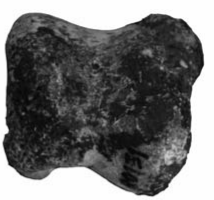

d3

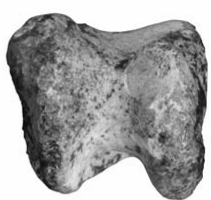

d4

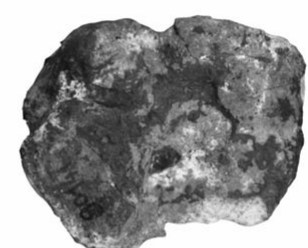

e2
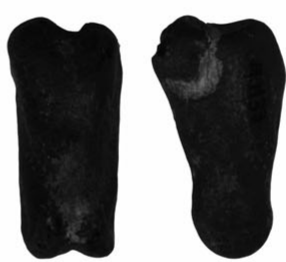

h1 h2

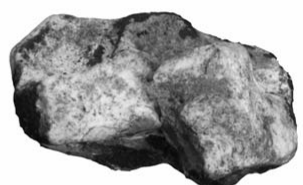

e3
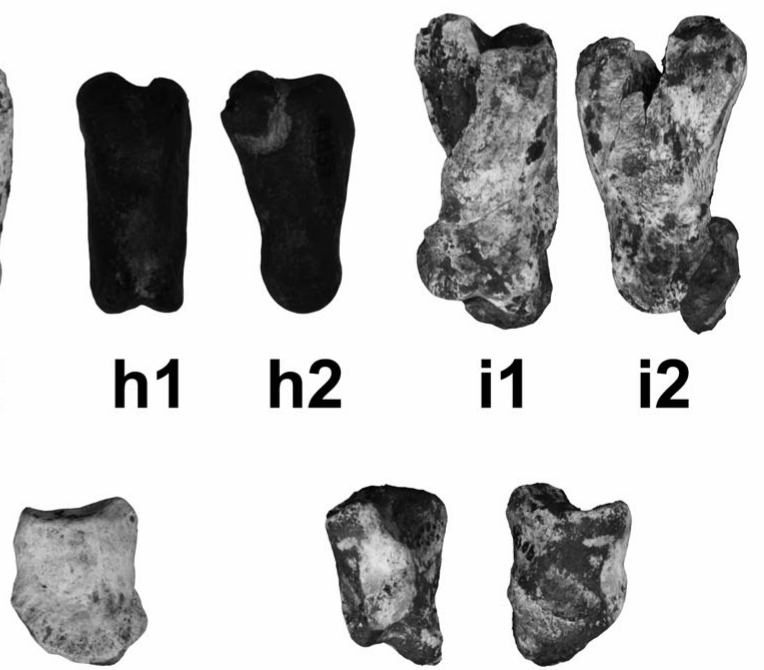

j2

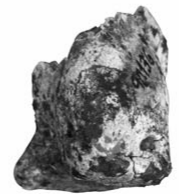

14

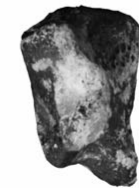

k1 k2

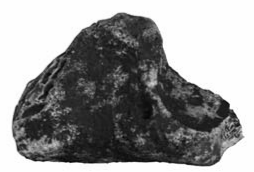

m

Figure 3. Postcranial material of Myotragus palomboi, n. sp. (a) Right magnum IMEDEA 90272: 1 - proximal view; 2 - distal view; 3 - palmar view; (b) right magnum IMEDEA 90273: 1 - proximal view; 2 - dorsal view; (c) left pisiform IMEDEA 90138: 1 - medial view; 2 - dorsal view; (d) left astragalus IMEDEA 90131: 1 - dorsal view; 2 - plantar view; 3 - proximal view; 4 - distal view; (e) left cubonavicular IMEDEA 90141: 1 - proximal view; 2 - distal view; 3 - dorsal view; (f) right metatarsal (holotype) IMEDEA 90140: 1 - dorsal view; 2 - medial view; (g) proximal phalanx IMEDEA 90132: 1 - dorsal view; 2 - axial view; (h) proximal phalanx IMEDEA 90133: 1 - dorsal view; 2 - abaxial view; (i) proximal phalanx IMEDEA 90274: 1 - dorsal view; 2 - axial view; (j) medial phalanx IMEDEA 90134: 1 - dorsal view; 2 - abaxial view; (k) medial phalanx IMEDEA 90135: 1 - dorsal view; 2 - abaxial view; (1) distal phalanx IMEDEA 90136: 1 - proximal view; 2 - solar view; 3 - axial view; 4 - distal view; (m) distal phalanx IMEDEA 90137: axial view. Scale bar $2 \mathrm{~cm}$. 
caprine astragali are generally short, but this bone is not significantly more robust in the $\mathrm{CdR}$ caprine. Values for the ratio Distal Breadth/Lateral Greatest Length $(\mathrm{Bd} / \mathrm{GLl} \times 100$; measurements following von den Driesch, 1976) reach 58.5 in the CdR caprine (Table 1) and 61.8 in $M$. pepgonellae $(\mathrm{n}=1)$ (in $M$. antiquus even more slender; mean $=57 ; \mathrm{n}=3$; range $=55.4$ 58.1). In the rest of the caprines studied, this value is larger than 65 except in Nemorhaedus goral (mean $=$ $61.2 ; \mathrm{n}=3$; range $=59.2-62.4)$, Nesogoral (63.6) and Gallogoral (56.2).

Additionally, resemblances between the $\mathrm{CdR}$ caprine and Myotragus rely on the shared deep, slender and closed U-shaped outline of the groove placed between the proximal trochleae when seen in dorsal view, and the not very rounded plantar articular facet for the calcaneus. In other caprines this groove is more Vshaped (Budorcas, Capra, Ovis, Nesogoral) or open Ushaped (Capricornis, Oreamnos, Nemorhaedus, Ovibos, Gallogoral) and the facet for the calcaneus is clearly rounded (P. Bover, unpub. Ph.D. thesis, Univ. Illes Balears, 2004).

\section{4.c.4. Cubonavicular}

Material. IMEDEA 90141, left (Fig. 3e).

This bone shows the dorsal margin fragmented. It has a square outline in proximal view and is slightly compressed proximo-distally. All attachment areas of ligaments are robust. The medial and central processes are partially eroded. In plantar view, the attachment area of the plantar ligament is large and rounded. A longitudinal groove located centrally along the plantar margin can be observed. Although it is partially abraded, the postero-external metatarsal process is blunt and robust. In distal view, it displays a deep and narrow groove to accommodate the tendon of the musculus peroneus longus that continues obliquely along the lateral margin of the bone and contacts the calcaneal articular facet. The antero-external metatarsal facet and the entocuneiform facet are rounded and concave, the former being almost half the size of the latter. The posterior cuneal facet is flat and very small. The postero-external metatarsal facet is also rounded. The calcaneal articular facet is broad medio-laterally and the internal and external astragal articular facets are deep and very concave, with a sharp crest between them. There is a deep and elongated notch on the plantolateral part of the internal astragal articular facet.

Characters shared by the CdR caprine and Myotragus are the robust attachment area for ligaments, the general proximo-distal compression of the bone, the shape of the distal articular facets, and the similar level at which the antero-external metatarsal facet and the entocuneiform facet are placed when seen in dorsal view.

\section{4.c.5. Metatarsal}

Material. IMEDEA 90140, right (Fig. 3f)
The metatarsal is a very short and wide bone (Fig. 4). It is more compressed dorso-plantarly than transversally. The plantar surface of the diaphysis is fairly flat and wide, and a shallow plantar longitudinal groove can be observed on the proximal and distal extremes, close to the epiphyses. The dorsal surface is also almost flat, and the dorsal longitudinal groove, wide and deep, can just be observed on the distal 1/3 of the diaphysis, especially on the area close to the intertrochlear incision.

In dorsal and plantar views, the transverse diameter is practically the same along all the diaphysis (that is, the lateral and medial margins of the diaphysis are parallel).

The proximal articular surface is almost flat, and the proximal metatarsal groove is deep, mainly at its central part. The posterior subfacet of the cubonavicular facet is abraded and does not allow us to conclude if it is high. The other facets and projections are also eroded. The morphology of the insertion of the lateral and medial extensor tendons cannot be fully resolved.

Although it is poorly preserved, the articulation surface of the trochlea is not as restricted as in Myotragus (Leinders, 1979).

The index of metatarsal robustness $(\mathrm{TD} / \mathrm{GL} \times$ 100; see Table 1) of the CdR caprine (22.8) is larger than in almost all fossil and extant caprines studied, except Myotragus. Among extant caprines, only Budorcas taxicolor has a similar, even higher, robustness index $($ mean $=23.7 ; \mathrm{n}=4$; range $=$ 22.2-24.6), but its morphology is completely different. While the tranverse diameters of the distal and proximal epiphyses in the CdR fossil are similar or slightly larger than the transverse diameter at midshaft, Budorcas displays a broad difference in transverse diameters, those of distal and proximal epiphyses being clearly wider than at midshaft (P. Bover, unpub. Ph.D. thesis, Univ. Illes Balears, 2004).

Among the fossils, only the Balearic caprines show a similar morphology and similar or larger robustness index. Two partially reconstructed metatarsals of $M$. pepgonellae have a robustness index of 32.6 and 36.2 (MNIB 59204 and 59205, respectively) and display almost parallel margins in dorsal view (Fig. 4). Identical morphology is shown by a metacarpal of the caprine from Ses Fontanelles, which has a robustness index of 27. Caprines show similar proportions in hind and forelimb metapodials. Thus, it is probable that the metatarsals of the caprine from Ses Fontanelles had a similar robustness index to the CdR caprine.

A similar morphology and robustness index to the CdR caprine is found in a metacarpal of a Bovidae indet. from the Baccinello-Cinigiano Basin (TuscoSardinian palaeoprovince, Late Miocene, Italy) that appears figured in Abbazzi et al. (2008, text-fig. 18). According to measurements taken from this figure, its robustness index falls around 22.7 and it also displays parallel margins in dorsal view. Unfortunately, no taxonomical assignment can be achieved yet regarding this bone, but the authors suggest that 

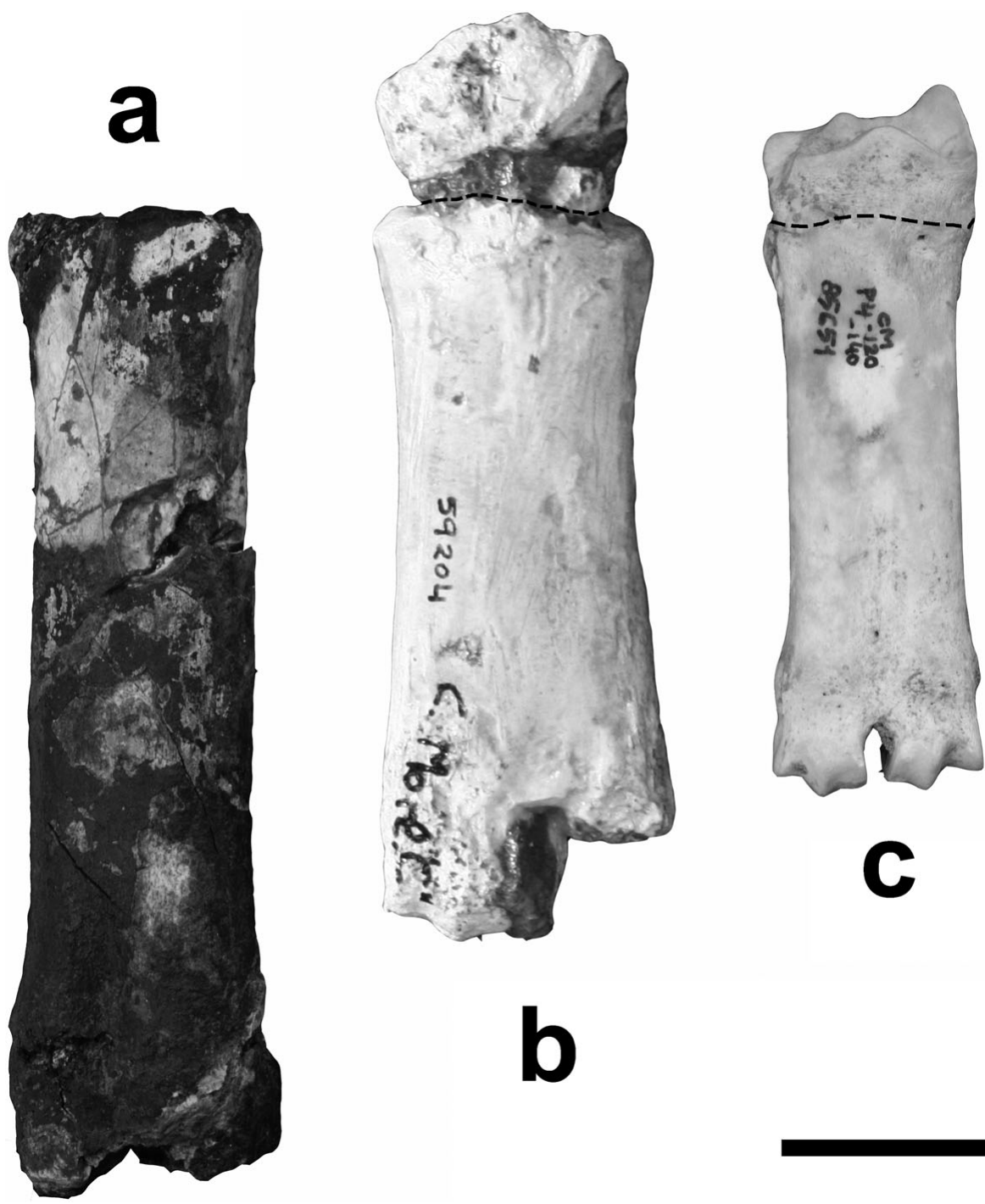

Figure 4. Metatarsals in dorsal view of (a) Myotragus palomboi n. sp. IMEDEA 90140 (holotype); (b) Myotragus pepgonellae MNIB 59204 and (c) Myotragus balearicus IMEDEA 85651. Dashed lines indicate the anatomical separation of metatarsal and cubonavicular (fused in the more modern species of Myotragus). Scale bar $2 \mathrm{~cm}$.

the metacarpal (and another one, not figured) could belong to Etruria viallii (?Antilopinae) or Turritragus casteanensis (Subfamily indet.).

\section{4.c.6. Proximal phalanx}

Material. IMEDEA 90132, 90133 and 90274 (Fig. $3 \mathrm{~g}-\mathrm{i})$.

Since none of the preserved CdR caprine phalanges can be assigned to the hind or the forelimb, all phalanges of recent and fossil caprines (when available) have been used for comparative purposes.

This is a robust phalanx. No remarkable differences between the transverse diameter of the epiphysis and the diaphysis can be observed. The medial and lateral walls of the diaphysis are parallel in dorsal view.

The proximal articular surface is broad, and the incision for the metapodial verticillus is shallow (as in Myotragus). In lateral view, it is concave with a rounded articular area (suggesting that joint movement was slightly restricted, but not as in Myotragus).
The dorsal surface of the diaphysis is convex, and the insertion area for the interdigital ligament is prominent and located slightly distal to the midshaft. There is no groove for the interosseum tendon.

The plantar/palmar surface is slightly concave in transverse section. The distal articular facets do not extend onto the plantar/palmar surface and their margins are flat-V shaped in this view. Sesamoidean facets are small and the insertion areas for the sesamoidean ligaments are also small and are oriented proximo-plantarly/palmarly.

No proximal phalanges of $M$. pepgonellae have been recovered as yet. Thus, for comparative analysis, the proximal phalanges of the more recent species $M$. antiquus have been used (Fig. 5). No proximal phalanges of the caprine from Ses Fontanelles or of Aragoral were available for study.

When compared to other caprines, the most relevant feature of the Caló den Rafelino phalanges is their great robustness (Mean Robustness Index, RI (TD/GL × 100; measurements following von den Driesch, 1976) 

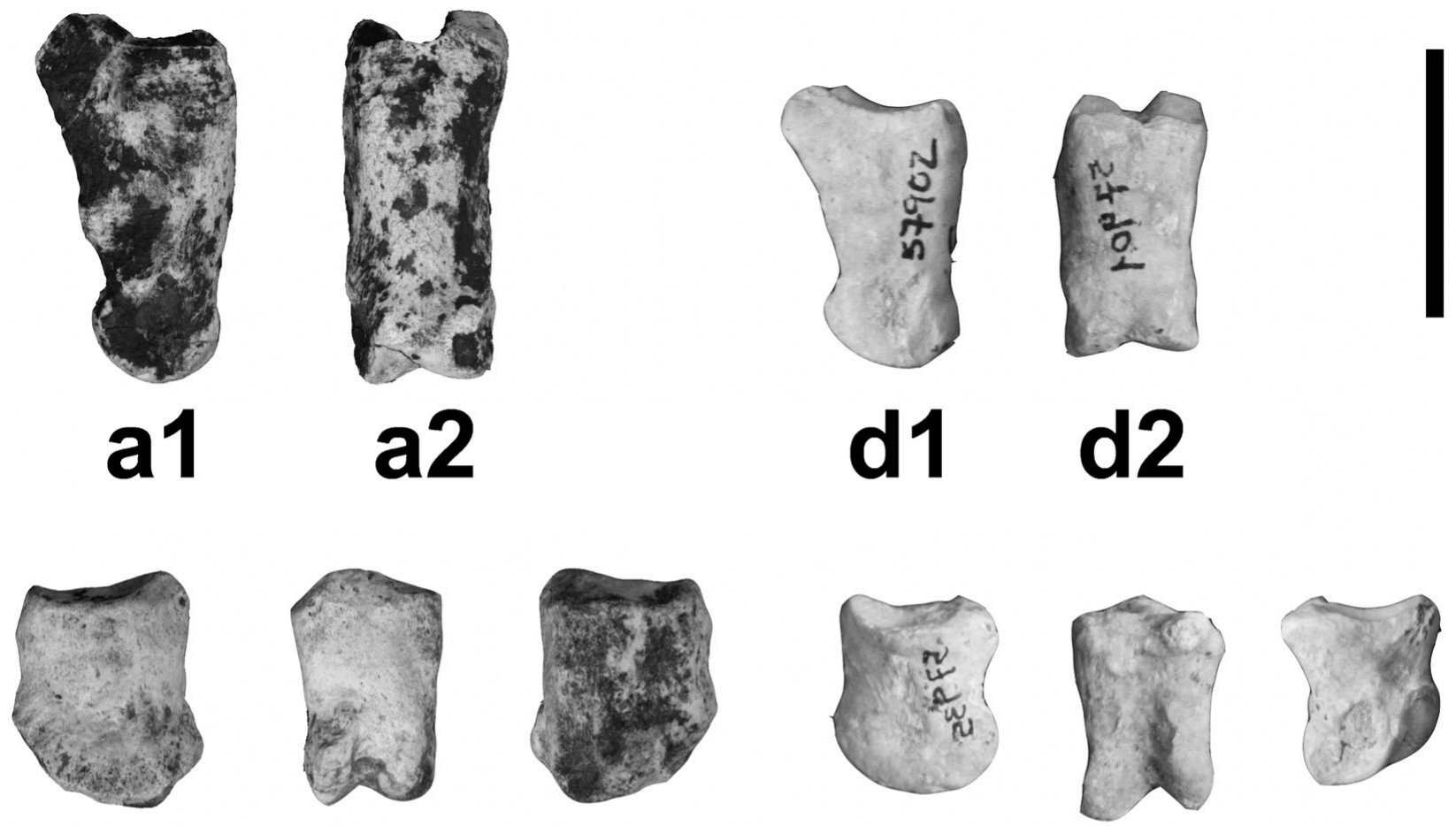

\section{b1}

b2
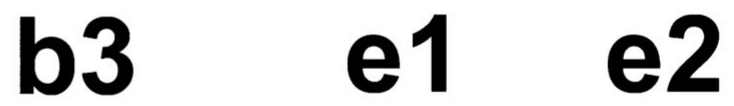

e3
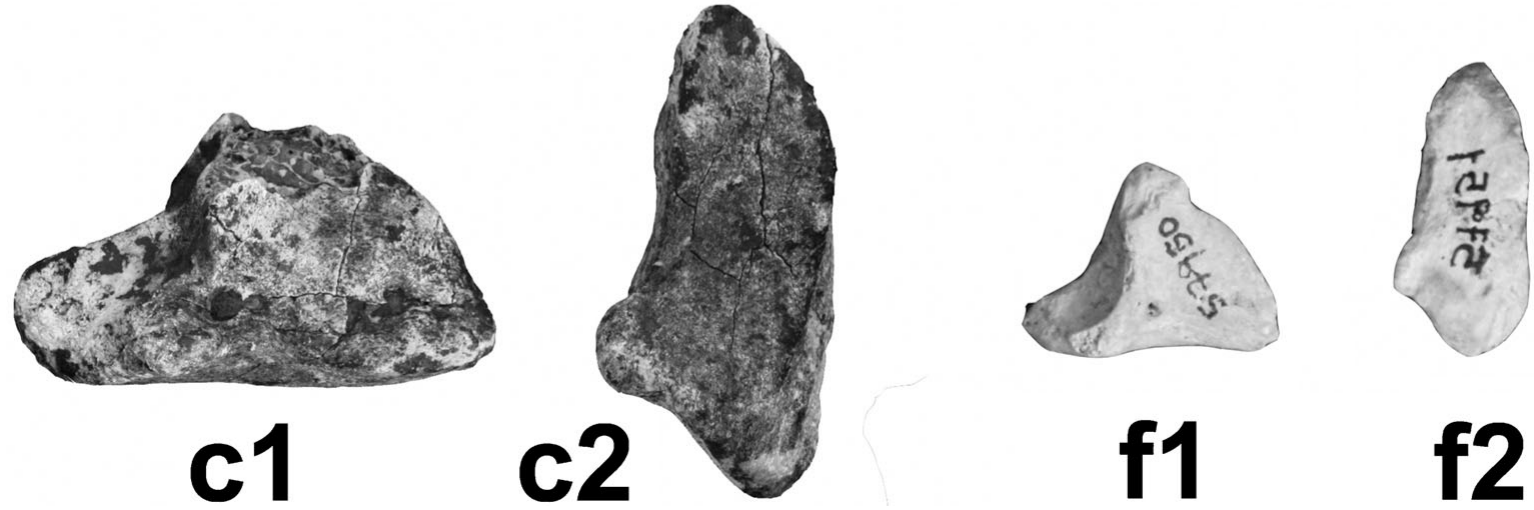

Figure 5. Comparison between phalanges of Myotragus palomboi n. sp. (a-c) and Myotragus antiquus (d-f). (a) Proximal phalanx IMEDEA 90132: 1 - axial view; 2 - dorsal view; (b) medial phalanx IMEDEA 90134: 1 - abaxial view; 2 - palmar/plantar view; 3 axial view; (c) distal phalanx IMEDEA 90136: 1 - axial view; 2 - solar view; (d) proximal phalanx: 1 - MNIB 57902: medial view; 2 - MNIB 57901: reversed, dorsal view; (e) medial phalanx: 1 - MNIB 57935, reversed, abaxial view; 2 - MNIB 57922, reversed, palmar/plantar view; 3 - MNIB 57928, axial view; (f) distal phalanx: 1 - MNIB 57950, axial view; 2 - MNIB 57951, reversed, solar view. Scale bar $2 \mathrm{~cm}$.

$=39.8 ; \mathrm{n}=2$ (one of the three phalanges, IMEDEA 90274, is fragmented); range $=38.2-41.4$ ). Among recent caprines, only Budorcas and Ovibos display larger or similar RI $(48.7(\mathrm{n}=1)$ and mean $=39.4(\mathrm{n}=$ 5 ; range $=36.7-44.9$ ), respectively), while among the fossils, only Myotragus antiquus shows larger values (even larger than $50 ;$ mean $=48 ; \mathrm{n}=5 ;$ range $=43.9$ 51.8).

In addition to their robustness, the phalanges of the CdR caprine and Myotragus share other morphological features (Fig. 5). The articular facets for the sesamoids are small. The protuberances where the ligaments between sesamoids and the proximal part of the phalanges are attached (sesamoidean ligaments, following Köhler, 1993) are also small and oriented in the proximo-plantar/palmar direction. In other caprines studied, these areas are rough surfaces oriented plantarly/palmarly and extend distalwards to approximately one-third of the diaphysis. Even in species with very robust proximal phalanges (Budorcas) this area is extended.

A characteristic feature of Myotragus (Leinders, 1979; Spoor, 1988) is the reduction of the articular movement between the proximal and medial phalanges, manifested in the flat morphology of the distal articular facet of the proximal phalanx (in lateral view). The caprine from Caló den Rafelino is similar to Norbertia, Gallogoral, Budorcas or Nesogoral in that respect, 
showing a rounded facet, but without an expansion of these facets on the dorsal and plantar/palmar surface of the diaphysis, as displayed by other caprine taxa (e.g. Capra and Ovis). In addition, the proximal articular surface is slightly reduced in the CdR caprine, Myotragus, Norbertia and Nesogoral (where it has a less concave morphology in lateral view), while in the other caprines it has a rounded outline.

\section{4.c.7. Medial phalanx}

Material. IMEDEA 90134 and 90135 (Fig. 3j, k).

Like the proximal phalanx, the second phalanx is short and robust. The post-articular plateau and the dorsal extensor process are very weak or almost absent. The articular fovea is concave.

No articular notches (in the sense of Köhler \& Moyà-Solà, 2001) can be observed on the distal and proximal articular surfaces. The distal articular lateral facet has a rounded outline, while the medial facet has a subtriangular outline in medial view (it is divided by a crest).

The distal articular facets are proximally expanded on the dorsal part and they tend to converge near the midshaft. On the plantar/palmar surface these facets extend to one-third of the distal extreme. While in one specimen (IMEDEA 90134) this surface is flat, in the other specimen (IMEDEA 90135) a sagittal groove along the whole diaphysis can be clearly observed. The lateral and medial extremes of the distal articular facets are approximately at the same level.

No medial phalanges of $M$. pepgonellae have been recovered as yet. Thus, for comparative analysis, medial phalanges of the derived species $M$. antiquus have been used (Fig. 5). No data for Budorcas, Aragoral or the caprine from Ses Fontanelles were available for study.

As in the proximal phalanx, the medial phalanx of the $\mathrm{CdR}$ caprine is very robust (mean $\mathrm{RI}=55 ; \mathrm{n}=2$; range $=54-56.1$; calculated as in proximal phalange; Table 1). Among the available living caprines, only Ovibos has a similar RI (mean $=55.2 ; \mathrm{n}=5$; range $=$ 48.9-61.5). Again, Myotragus is the taxon with the greatest RI, with values close to 60 (mean $=58.6 ; \mathrm{n}=$ 5 ; range $=50.3-70.3$ ). The CdR caprine and Myotragus also share characteristic features not observed in the other caprines studied, such as the very weak morphology of the postarticular plateau and the dorsal extensor process, and an important reduction in the articular movements (as derived from the flat proximal and distal articular facets in lateral view) (Fig. 5). This morphology of the articular facet is also displayed by Ovibos. In both fossil taxa, the lateral and medial extremes of the distal articular facets are approximately at the same level, as in Nesogoral, Capricornis and Gallogoral.

\section{4.c.8. Distal phalanx}

Material. IMEDEA 90136 and 90137 (Fig. 31, m).
Like other phalanges, the distal phalanx is short and robust. Both phalanges available are broken in the processus extensorius zone. The dorsal ridge (on the dorsal border) is rounded. On the wedge/interdigital margin of the plantar or palmar surface of the phalanx there is a prominent protuberance extended axially (clearly visible in IMEDEA 90137, but IMEDEA 90136 is abraded and this protuberance cannot be observed). The solar (distal) border is flat or slightly concave. The border of the plantar wedge (where the flexor digitorum profundus inserts) is poorly developed. In the coronary (proximal) border, the articular surface is broad (in accordance with the size of the articular surface in the medial phalanx) and the crest that separates the two facets is axially curved. The articular surface is open (that is, not very rounded). The apex is blunt. As IMEDEA 90136 is abraded, the protuberance for the extensor insertion is not visible and the dorsal border is also eroded. In this specimen a central notch can be observed on the articular facets, while in IMEDEA 90137 it is absent.

In lateral view the dorsal border is strongly convex, almost rounded. The axial surface is concave and has a small crest on the anterior part, running in the dorsoplantar direction, and the axial foramen is at the same level as the dorsal extreme of the crest on the articular facet.

No distal phalanges of $M$. pepgonellae have been recovered as yet. Thus, for comparative analysis, distal phalanges of the derived species $M$. antiquus have been used (Fig. 5), in addition to distal phalanges of Norbertia (fragmented), Nesogoral, Gallogoral, Capra, Ovis, Oreamnos, Nemorhaedus and Ovibos.

The robustness of the distal phalanx in the CdR caprine is 33.6 ( $\mathrm{n}=1$; phalanx IMEDEA 90137 is fragmented); measured as the ratio middle breadth of the sole/diagonal length of the sole $(\mathrm{MBS} / \mathrm{DLS} \times$ 100; Table 1), following von den Driesch, 1976). Only Ovibos $($ mean $=33.2 ; \mathrm{n}=5 ;$ range $=30.6-35.2)$ and Myotragus $($ mean $=39.7 ; \mathrm{n}=5$; range $=35.2$ 42) display similar or greater robustness. The CdR caprine shares with the other studied caprines an almost rounded shape of the distal part of the dorsal ridge. In Myotragus, a prominent protuberance extended axially on the wedge of the phalanx can also be observed, although it is not as developed as in the CdR caprine (Fig. 5). In the other caprines this protuberance is a weak and elongated rough area (except in Ovibos, where this protuberance projects axially from the broad articular facet). Broad articular facets and practically flat soles are shared by Ovibos, Myotragus and the CdR caprine.

\section{Systematic palaeontology}

The CdR caprine and Myotragus share the following combination of characters: (1) an extremely short and robust metatarsal, which is columnar and has parallel walls; (2) great robustness in all postcranial remains studied; (3) similar shape of $\mathrm{P} 2$ and $\mathrm{P} 3$ (compared to M. pepgonellae 
and M. antiquus); (4) cubonavicular compressed proximodistally, with robust attachment area for ligaments; shape of distal articular facets, with antero-external metatarsal and entocuneiform facets placed at same level when seen in dorsal view; (5) astragalus with deeper, more slender and closed U-shaped outline of the groove placed between the proximal trochleae in dorsal view, and with plantar articular facet for the calcaneus not very rounded; (6) in proximal phalanges, articular facets for sesamoids small, and areas where sesamoidean ligaments insert also small and oriented, as a blunt protuberance, in proximo-plantar/palmar direction; (7) in medial phalanges, very weak postarticular plateau and dorsal extensor process, and important reduction in articular movements (manifested in flattened proximal and distal articular facets in lateral view); (8) in distal phalanges, presence of a prominent protuberance extended axially beyond the wedge of the phalanx.

In accordance with all of these similarities, the CdR caprine is here included in the genus Myotragus. Nevertheless, there are remarkable differences between the Myotragus from Caló den Rafelino and M. pepgonellae (and also the rest of species of Myotragus), namely: (1) lower robustness index in all available postcranial remains (metatarsal, phalanges, astragalus, etc.) in the CdR Myotragus; (2) i3 of 'normal' shape, that is, with a more rectangular wear surface, and with enamel surrounding all the crown, and not expanded to the root; (3) presence of a larger p2, with a reduced paraconid-parastylid complex. These differences warrant the description of a new species of Myotragus, as follows.

Class MAMMALIA Linnaeus, 1758

Order ARTIODACTYLA Owen, 1848

Family BOVIDAE Gray, 1821

Subfamily CAPRINAE Gray, 1821

Genus Myotragus Bate, 1909

Myotragus palomboi n.sp.

Holotype. Right metatarsal (IMEDEA 90140).

Paratypes. The remaining material described herein.

Type locality. Caló den Rafelino, Manacor (Mallorca; Balearic Islands, Spain).

Age. Earliest Early Pliocene.

Etymology. The species name is honouring Prof. Maria Rita Palombo, singular contributor to the development of palaeontological studies on Mediterranean mammals.

Diagnosis. Myotragus with short and robust metapodials, longer than in other representatives of the genus; i3 neither hypsodont nor ever-growing, chisel-shaped and with enamel just covering the erupted area of the tooth (that is, not elongated nor with enamel covering the labial part of the root); p2 relatively large, displaying important reduction of paraconid-parastylid complex.

\section{Discussion and conclusions}

This new species of Myotragus represents the earliest record of the genus. No bovid remains are known from the Middle Miocene of the Balearic Islands (Mein \& Adrover, 1982; Adrover et al. 1985; Quintana \& Agustí, 2007). The ancestor of the CdR caprine presumably reached the island during the Messinian Salinity Crisis (MSC) (5.6-5.32 Ma ago; e.g. Clauzon et al. 1996; Krijgsman et al. 1999). Myotragus palomboi n.sp. should be considered as the first representative of the

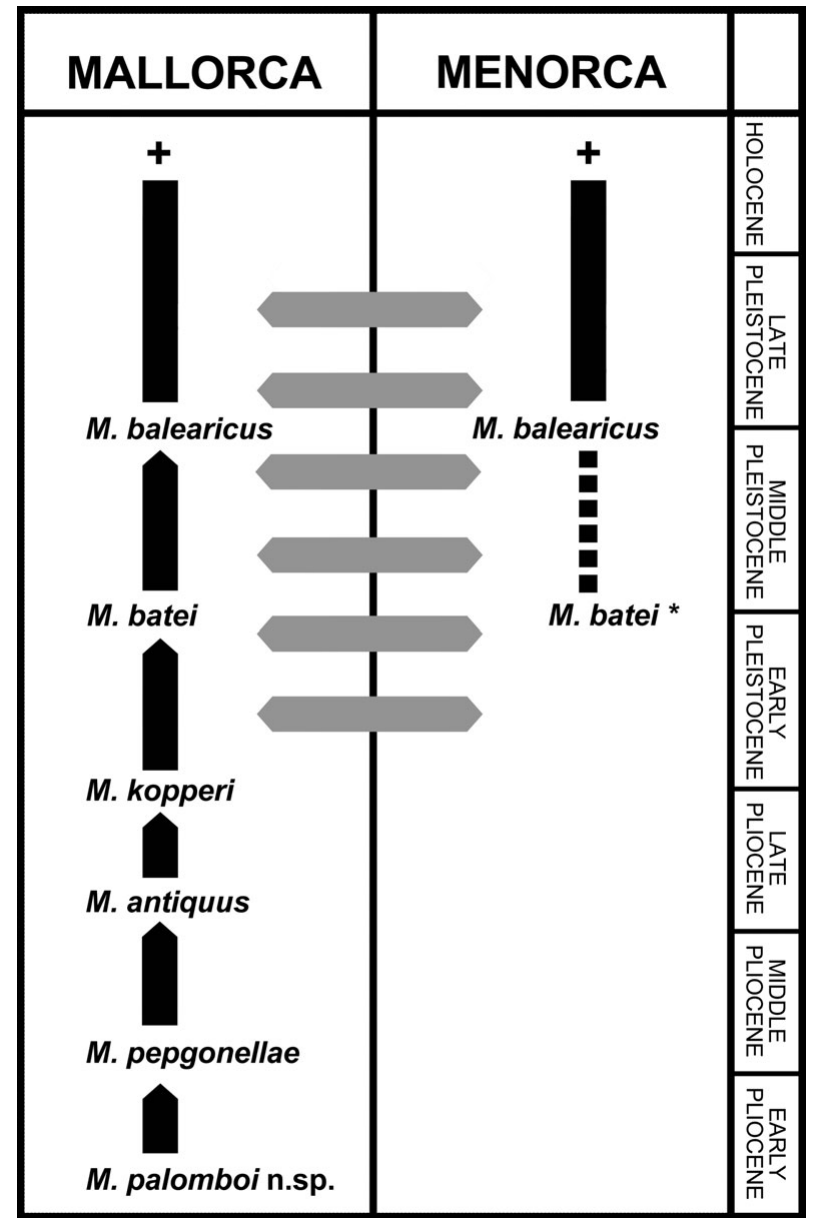

Figure 6. Phylogenetic relationships among the different chronospecies of the Myotragus lineage. ${ }^{*}=$ the species formerly described as $M$. binigausensis by Moyà-Solà \& Pons-Moyà (1980) was synonymized to M. batei by Bover \& Alcover (2000) but this view is currently under discussion (see Moyà-Solà et al. 2007). Grey lines indicate contact and faunal exchange between Mallorca and Menorca during Quaternary glaciations. + = extinction of the lineage.

Myotragus phylogenetic lineage (Fig. 6), in which a progressive reduction in length of metapodials and a reduction in number of incisiforms and premolars took place (e.g. Alcover, Moyà-Solà \& Pons-Moyà, 1981). Accordingly, M. palomboi displays a metapodial longer than the previously considered earliest known representative of the genus, $M$. pepgonellae, but it is shorter than the condition exhibited in other fossil (and extant) European caprines. It should be considered as the direct ancestor of $M$. pepgonellae. This is also suggested by the reduction in size of p2 (promoted by the reduction of the paraconid-parastylid complex). This feature agrees with the evolutionary scenario for the genus, with a presumed extremely reduced $\mathrm{p} 2$ (or remains of $\mathrm{dp} 2$ ) in $M$. pepgonellae and complete loss of this tooth in their descendants (Alcover, Moyà-Solà \& Pons-Moyà, 1981). The chronology proposed for the taxon from Caló den Rafelino also fits into the proposed palaeobiogeographical scenario: while $M$. pepgonellae has been considered to be Early/Middle Pliocene in age (Moyà-Solà \& Pons-Moyà, 1982; Pons-Moyà, 1990), 
M. palomboi is attributed to the beginning of the Early Pliocene.

The similarities between the faunal assemblages of the Late Miocene/Early Pliocene site at Ses Fontanelles (Eivissa: Moyà-Solà et al. 1999) and Caló den Rafelino could suggest that they are closely related. Ses Fontanelles has rendered two bovids (the caprine reported here and an Antilopini), two rodents (a gerbillid Protatera sp. and a glirid Eliomys sp.), an insectivore and a leporid (Hypolagus sp. according to Quintana et al. in press), as well as several reptiles (Podarcis sp. and a tortoise). In the Caló den Rafelino deposit, at least a caprine (here described as M. palomboi), a glirid, an insectivore, a Hypolagus, a tortoise and a small lacertid have been recorded, together with other mammalian and reptilian species (Bover et al. 2007). Thus, it can be suggested that these species reached Mallorca and Eivissa from the mainland during the Messinian Salinity Crisis.

Some remarkable similarities can be traced between the metatarsal of M. palomboi and the metacarpal of an unidentified bovid from Baccinello figured in Abbazzi et al. (2008), although it is difficult to go further than Palombo et al. (2006a) in the establishment of a clear relationship between Myotragus and the Italian insular bovids. The same holds when trying to establish the mainland phylogenetic origin of Myotragus. As previously mentioned, both Aragoral (Upper Vallesian, MN10) and Norbertia (Turolian-Ruscinian boundary, MN13/14) display robust metapodials, weak upper premolar styles and reduced p2 (Köhler, Moyà-Solà \& Morales, 1995; Alcalá \& Morales, 1997), and they could be considered as putative ancestors of Myotragus, but their relationships cannot be clearly established on the basis of current evidence.

The reduction in size of Myotragus postcranial long bones and the progressive loss of teeth have been related to a process of evolution in insular conditions (e.g. Alcover, Moyà-Solà \& Pons-Moyà, 1981; Moyà-Solà \& Pons-Moyà, 1982). In M. palomboi, the reduction in size of the metatarsal and second lower premolar suggests that this species represents a first stage in this process. The faunal assemblage from Caló den Rafelino, with a reduced number of species, all of them endemic, and the lack of important ecological categories (as carnivores) among them, also suggest some kind of insular effect, or at least the presence of important barriers for dispersal of mainland taxa. Despite all of this evidence, the similar evolutionary pattern observed in mainland caprines such as Aragoral and Norbertia (Köhler, Moyà-Solà \& Morales, 1995; Alcalá \& Morales, 1997), and the presence of fossil insular bovids with long and slender metapodials and dentition like Nesogoral, do not allow conclusions to be formed on this subject. The caprine that arrived in the Balearics may already have displayed short metapodials before the colonization event took place, as Marcus (1998) suggested. Nevertheless, its extremely short metapodials and teeth reduction are probably best explained as a result of island evolutionary processes (see Van der Made, 2005 for documentation and interpretation of the extent of the pattern of feet shortening of artiodactyls on islands).

Future findings and work are necessary in order to understand the taxonomy of the earlier species of Myotragus, the systematics of insular Mediterranean bovids and to understand evolutionary patterns on these islands.

Acknowledgements. Thanks are due to Maria Rita Palombo (Roma, Italy), Bienvenido Martínez Navarro (Tarragona, Spain), Jan Van der Made (Madrid, Spain), and an anonymous referee, who reviewed the manuscript. Miquel Trias (Palma, Spain) provided the topography of the deposit. This work is a contribution to the project CGL2007-62047/BTE of Dirección General de Investigación, Ministerio de Ciencia e Innovación. One of the authors (PB) benefits of a JAE-DOC (CSIC) contract (Junta para la Ampliación de Estudios).

\section{References}

Abbazzi, L., Angelone, C., Arca, M., Barisone, G., Bedeti, C., Delfino, M., Kotsakis, T., Marcolini, F., Palombo, M. R., Pavia, M., Piras, P., Rook, L., TORRe, D., Tuveri, C., VAlli, A. M. F. \& Wilkens, B. 2004. Plio-Pleistocene fossil vertebrates of Monte Tuttavista (Orosei, Eastern Sardinia, Italy), an overview. Rivista Italiana di Paleontogia e Stratigrafia 110, 60328.

AbBazZI, L., Delfino, M., Gallai, G., Trebini, L. \& RoOK, L. 2008. New data on the vertebrate assemblage of Fiume Santo (North-West Sardinia, Italy), and overview on the late Miocene Tusco-Sardinian palaeobioprovince. Palaeontology 51, 425-51.

Adrover, R., Agustí, J., MoyÀ, S. \& PONS, J. 1985. Nueva localidad de micromamíferos insulares del mioceno medio en las proximidades de San Lorenzo en la isla de Mallorca. Paleontologia i Evolució 18, 121-9.

Agustí, J. \& MoYÀ-SOLÀ, S. 1990. Neogene-Quaternary mammalian faunas of the Balearics. In International Symposium on Biogeographical aspects of insularity (ed. A. Azzaroli), pp. 459-68. Atti dei Convegni Lincei 85.

AlcalÁ, L. \& Morales, J. 1997. A primitive caprine from the Upper Vallesian of La Roma 2 (Alfambra, Teruel, Aragón, Spain). Comptes Rendus de l'Académie des Sciences de Paris IIa 324, 947-53.

AlcalÁ, L., Morales, J. \& MoYÀ-SolÀ, S. 1989-1990. El registro fósil neógeno de los bóvidos (Artiodactila, Mammalia) de España. Palentologia i Evolució 23, 6773.

Alcover, J. A. 1976. L'evolució de Myotragus Bate 1909 (Artiodactyla, Rupicaprini), un procés lligat al fenomen de la insularitat. Butlletí de la Institució Catalana d'Història Natural, Secció Geologia 1, 59-94.

Alcover, J. A. 2008. The first Mallorcans: prehistoric colonization in the Western Mediterranean. Journal of World Prehistory 21, 19-84.

Alcover, J. A., MoYÀ-Solà, S. \& Pons-MoYA, J. 1981. Les Quimeres del Passat. Els Vertebrats Fòssils del PlioQuaternari de les Balears i Pitiüses. Palma: Edit. Moll, $260 \mathrm{pp}$.

ANDREWS, C. W. 1915. A description of the skull and skeleton of a peculiarly modified rupicaprine antilope (Myotragus balearicus Bate), with a notice of a new variety Myotragus balearicus var. major. Philosophical Transactions of the Royal Society of London B 206, 281305. 
Azzaroli, A., Boccaletti, M., Delson, E., Moratti, G. \& TORRE, D. 1986. Chronological and paleogeographical background to the study of Orepithecus bambolii. Journal of Human Evolution 15, 533-40.

BATE, D. M. A. 1909. Preliminary note on a new artiodactyle from Mallorca Myotragus balearicus, gen. et sp. nov. Geological Magazine 6, 385-9.

Bizon, G., Bizon, J. J., Bourrouilh, R. \& MASSA, D. 1973. Présence aux iles Baléares (Méd. Occ.) de sédiments "messiniens" déposés dans une mer ouverte, à salinité normale. Comptes Rendus de l'Académie des Sciences de Paris 277, 985-8.

Bover, P. \& Alcover, J. A. 1999. The evolution and ontogeny of the dentition of Myotragus balearicus Bate, 1909 (Artiodactyla, Caprinae): evidence from new fossil data. Biological Journal of the Linnean Society 68, 40128.

Bover, P. \& Alcover, J. A. 2000. La identitat taxonòmica de Myotragus binigausensis Moyà-Solà i Pons-Moyà 1980. Endins 23, 83-8.

Bover, P. \& Alcover, J. A. 2003. Understanding Late Quaternary extinctions: the case of Myotragus balearicus Bate 1909. Journal of Biogeography 30, 771-81.

Bover, P. \& Alcover, J. A. 2005. A taxonomic approach to the insular caprines of the Gymnesic Islands (western Mediterranean Sea). Quaternaire 2, 213-20.

Bover, P., Fornós, J. J. \& Alcover, J. A. 2005. Carpal bones, carpal fusions and footprints of Myotragus: clues for locomotion and behavior. In Proceedings of the International Symposium "Insular Vertebrate Evolution: the Palaentological Approach" (eds J. A. Alcover \& P. Bover), pp. 59-72. Monografies de la Societat d'Història Natural de les Balears 12.

Bover, P., QuintANA, J., Agustí, J., BAILON, S. \& AlCOVER, J. A. 2007. Caló den Rafelino: an early Pliocene site in Mallorca, Western Mediterranean. In Libro de resúmenes del VII Simposio Internacional de Zoología, p. 119. Topes de Collantes (Sancti Spiritus, Cuba).

Clauzon, G., Suc, J.-P., Gautier, F., Berger, A. \& LOUTRE, M. F. 1996. Alternate interpretation of the Messinian salinity crisis: controversy resolved? Geology 24, 363-6.

Dehaut, E. G. 1911. Animaux fossiles du Cap Figari. Matériaux pour servir à l'histoire zoologique et paléontologique des îles de Corse et de Sardaigne (Paris) 3, 53-9.

FORNÓS, J. J. 1998. Karst collapse phenomena in the Upper Miocene of Mallorca (Balearic Islands, Western Mediterranean). Acta Geologica Hungarica 42, 23750.

GENTRY, A. W. 1992. The subfamilies and tribes of the family Bovidae. Mammalian Review 22, 1-32.

GenTRY, A. W. \& HoOKER, J. J. 1988. The phylogeny of the Artiodactyla. In The phylogeny and classification of Tetrapods, Volume 2: Mammals (ed. M. J. Benton), pp. 235-72. Oxford: Clarendon Press.

Gentry, A. W., Rössner, G. E. \& Heizmann, P. J. 1999. Suborder Ruminantia. In Land mammals of Europe (eds G. E. Rössner \& K. Heissig), pp. 225-53. München: Verlag Dr Friederich Pfeil.

GliozzI, E. \& MALATESTA, A. 1980. The Quaternary goat of Capo Figari (Northeastern Sardinia). Geologica Romana 19, 295-347.

GómeZ-Pujol, L., BALAGUER, P. \& ForNós, J. J. 2007. El litoral de Mallorca: síntesi geomòrfica. In Geomorfologia litoral: Migjorn i Llevant de Mallorca (eds J. J. Fornós, J. Ginés \& L. Gómez-Pujol), pp. 39-59. Monografies de la Societat d'Història Natural de les Balears 15.
GRAY, J. E. 1821. On the natural arrangement of vertebrose animals. London Medical Repository 15, 296-310.

GuERIN, C. 1965. Gallogoral (nov.gen.) meneghinii (Rütimeyer, 1878). Un rupicaprine du Villafranchien d'Europe Occidentale. Documents des Laboratoires de Géologie de la Faculté des Sciences de Lyon 11, 1353.

HÜRZELER, J. 1983. Un alcélaphiné aberrant des "Lignites de Grosseto" en Toscane. Comptes Rendus de l'Académie des Sciences de Paris III 296, 243-9.

HÜRZELER, J. \& ENGESSER, B. 1976. Les faunes de mammifères néogenes du Basin de Baccinello (Grosseto, Italia). Comptes Rendus de l'Académie des Sciences de Paris 283, 333-6.

KöHLER, M. 1987. Boviden des türkischen Miozäns (Känozoikum und Braunkohlen der Türkei). Paleontologia i Evolució 21, 133-246.

KöHLER, M. 1993. Skeleton and habitat of recent and fossil ruminants. Münchner Geowissenschaftliche Abhandlungen A 25, 1-88.

KÖHLER, M. \& MOYÀ-SOLÀ, S. 2001. Phalangeal adaptations in the fossil insular goat Myotragus. Journal of Vertebrate Paleontology 21, 621-4.

KÖHLER, M., MOYÀ-SOLÀ, S. \& MORALES, J. 1995. The vertebrate locality Maramena (Macedonia, Greece) at the Turolian-Ruscinian boundary (Neogene). 15. Bovidae and Giraffidae (Artiodactyla, Mammalia). Münchner Geowissenschaftliche Abhandlungen A 28, 167-80.

Krijgsman, W., Hilgen, F. J., RAFFi, I., Sierro, F. J. \& WILSON, D. S. 1999. Chronology, causes and progression of the Messinian salinity crisis. Nature 400, $652-5$.

Lalueza-Fox, C., Castresana, J., SAmpietro, L., MARQuÉS-Bonet, T., Alcover, J. A., \& BERTRANPETIT, J. 2005. Molecular dating of caprines using ancient DNA sequences of Myotragus balearicus, an extinct endemic Balearic mammal. BMC Evolutionary Biology 5, 70, doi:10.1186/1471-2148-5-70, 11 pp.

LEINDERS, J. J. M. 1979. On the osteology and function of the digits of some ruminants and their bearing on taxonomy. Zeitschrift für Säugetierkunde 44, 305-18.

LinNAEUS, C. 1758. Systema naturae per regna tria naturae secundum classes, ordines, genera, species cum characteribus, differentiis, sinonimis, locis (Regnum animale), 10th ed. Holmiae: Laurentius Salvius, $824 \mathrm{pp}$.

MARCUS, L. F. 1998. Variation in selected skeletal elements of the fossil remains of Myotragus balearicus, a Pleistocene bovid from Mallorca. Acta Zoologica Academiae Scientiarium Hungaricae 44, 113-37.

MEAD, J. I. \& TAYLOR, L. H. 2005. New species of Sinocapra (Bovidae, Caprinae) from the Lower Pliocene Panaca Formation, Nevada, USA. Palaeontologia Electronica 8, 11A, 20 pp.

MEIN, P. \& ADROVER, R. 1982. Une faunule de mammifères insulaires dans le Miocène Moyen de Majorque (Iles Baléars). Geobios, Mémoire spéciale 6, 451-63.

MoyÀ-SolÀ, S., Agustí, J. \& PONS-MoyÀ, J. 1984. The Mio-Pliocene insular faunas from the West Mediterranean. Origin and distribution factors. Paleobiologie Continentale 14, 347-57.

MoyÀ-SolÀ, S., KÖHLER, M., AlbA, D. \& Pons-MoyÀ, J. 2007. El significado de Myotragus batei y M. binigasensis en la evolución del género Myotragus (Bovidae, Mammalia) en la islas Baleares. In Geomorfologia litoral i Quaternari. Homenatge a Joan Cuerda Barceló (eds G. X. Pons \& D. Vicens), pp. 155-80. Monografies de la Societat d'Història Natural de les Balears 14. 
MoyÀ-SolÀ, S., Pons-MoyÀ, J., Alcover, J. A. \& Agustí, J. 1984. La fauna de vertebrados neógeno-cuaternaria de Eivissa (Pitiuses). Nota preliminar. Acta Geològica Hispànica 19, 33-5.

MOYÀ-SOLÀ, S. \& PONS-MoYÀ, J. 1980. Una nueva especie del género Myotragus Bate, 1909 (Mammalia, Bovidae) en la isla de Menorca: Myotragus binigausensis nov. sp. Implicaciones paleozoogeográficas. Endins 7, 3747.

MoYÀ-SolÀ, S. \& Pons-MoYÀ, J. 1982. Myotragus pepgonellae nov. sp. un primitivo representante del género Myotragus Bate, 1909 (Bovidae, Mammalia) en la isla de Mallorca (Baleares). Acta Geològica Hispànica 12, $77-87$.

MoyÀ-Solà, S., Quintana, J., Alcover, J. A. \& KöHLer, M. 1999. Endemic island faunas of the Mediterranean Miocene. In Land mammals of Europe (eds G. E. Rössner \& K. Heissig), pp. 435-42. München: Verlag Dr. Friederich Pfeil.

OWEn, R. 1848. On the Archetype and Homologies of the Vertebrate Skeleton. London, UK: J. Van Voorst, $203 \mathrm{pp}$.

Palombo, M. R., Bover, P., Valli, A. M. F. \& Alcover, J. A. 2006a. The Plio-Pleistocene endemic bovids from the Western Mediterranean islands: knowledge, problems and perspectives. Hellenic Journal of Geosciences 41, 153-62.

Palombo, M. R., Valli, A. M. F., Arca, M. \& Tuveri, C. 2006b. A new bovid, Asoletragus gentryi n. gen. et n. sp., from Monte Tuttavista (Orosei, Eastern Sardinia, Italy). Rivista Italiana di Paleontologia e Stratigrafia 112, 459-71.

Pomar, L., Rodríguez-Perea, A., SABat, F. \& Fornós, J. J. 1990. Neogene stratigraphy of Mallorca island. Paleontología i Evolució 2, 271-320.

PONS-MOYÀ, J. 1990. Estratigrafía y fauna del yacimiento kárstico de Cala Morlanda (Manacor, Mallorca). Endins 16, 59-62.

QUINTANA, J. \& AGUSTÍ, J. 2007. Los mamíferos insulares del Mioceno medio y superior de Menorca (islas Baleares, Mediterráneo occidental). Geobios 40, 677-87.
Quintana, J., Bover, P., Alcover, J. A., Agustí, J. \& BAILÓN, S. In press. Presence of Hypolagus Dice 1917 (Lagomorpha, Leporidae, Archaeolaginae) in the Neogene of the Balearic Islands (Western Mediterranean). Description of Hypolagus balearicus sp. nov. Geobios.

Ramírez, O., Gigli, E., Bover, P., Alcover, J. A., Bertranpetit, J., CASTRESANA, J. \& LALUEZA-FoX, C. 2009. At the limits of paleogenomics: shotgun sequencing from an extinct Mediterranean caprine. PLoS ONE 4, e5670, doi:10.1371/journal.pone.0005670, 6 pp.

Robledo, P. \& Pomar, L. 2000. Upper Miocene karst collapse structures of the East Coast, Mallorca, Spain. Acta Carsologica 29, 177-84.

SCHALLER, O. (ed.) 1992. Illustrated Veterinary Anatomical Nomenclature. Stuttgart: Ferdinand Enke Verlag, $516 \mathrm{pp}$.

SHINDLER, K. 2005. Discovering Dorothea: the life of pioneering fossil-hunter Dorothea Bate. London: Harper Collins, $390 \mathrm{pp}$.

SpOOR, C. F. 1988. The limb bones of Myotragus balearicus Bate, 1909. Proceedings of the Koninklijke Nederlandse Akademie van Wetenschappen B 91, 295-308.

VAN DER MADE, J. 1999. Biogeography and stratigraphy of the Mio-Pleistocene mammals of Sardinia and the description of some fossils. In Elephants have a snorkel! (eds J. W. F. Reumer \& J. de Vos), pp. 337-60. Deinsea 7.

VAN DER MADE, J. 2005. The fossil endemic goat Nesogoral cenisae n.sp. from Campidano, Sardinia. Cursorial adaptation in insular environment. In Proceedings of the International Symposium "Insular Vertebrate Evolution: the Palaentological Approach" (eds J. A. Alcover \& P. Bover), pp. 347-68. Monografies de la Societat d'Història Natural de les Balears 12.

VisLOBOKOVA, I. A. 2006. Associations of ruminants in Miocene ecosystems of Eastern Alpine Region. Paleontological Journal 40, 438-47.

VON DEN DRIESCH, A. 1976. A guide to the measurement of animal bones from archaeological sites. Peabody Museum of Archaeology and Ethnology Bulletin 1, 1117. 